\title{
IMPROVING EFFECT OF EXOGENOUS NICKEL NITRATE APPLICATION ON PHYSIO-BIOCHEMICAL FEATURES, NITROGEN METABOLISM AND EARLY GROWTH OF RICE
}

\author{
ZHANG, T. T. ${ }^{1,2 \#}-$ HE, L. $X^{1,2 \#}-$ ASHRAF, U. ${ }^{1,2,3 \#}-$ TONG, T. Y. ${ }^{1,2 \#}-$ CHENG, Y. ${ }^{1}-$ SABIR, S.-U.-R. ${ }^{3}$ \\ -ZHENG, A. X. ${ }^{1,2}-$ LU, R. H. ${ }^{1}-$ LAI, R. F. ${ }^{1,2}-$ FENG, H. Y. ${ }^{1}-$ TANG, X. R. ${ }^{1,2 *}$ \\ ${ }^{I}$ Department of Crop Science and Technology, College of Agriculture, South China Agricultural \\ University, 510642 Guangzhou, PR China \\ ${ }^{2}$ Scientific Observing and Experimental Station of Crop Cultivation in South China, Ministry of \\ Agriculture, 510642 Guangzhou, PR China \\ ${ }^{3}$ Department of Botany, University of Education, Lahore, Faisalabad-Campus, 38000, Punjab, \\ Pakistan \\ ${ }^{\#}$ These author have contributed equally to this work \\ *Corresponding author \\ e-mail: tangxr@scau.edu.cn; phone/fax: +20-8528-0204-618
}

(Received $16^{\text {th }}$ Jul 2018; accepted $31^{\text {st }}$ Oct 2018)

\begin{abstract}
High $\mathrm{Ni}^{2+}$ levels are toxic to plant growth; however, being a micro-nutrient, its application and/or presence in low concentration may improve plant growth. Present study investigated the effects of exogenous $\mathrm{Ni}$ application on morpho-physiological attributes of two rice cultivars in China i.e., Yuxiangyouzhan and Meixiangzhan 2. Nickel was applied exogenously to 11 days old seedlings as $\mathrm{Ni}\left(\mathrm{NO}_{3}\right)_{2}$ in a solution form in the following concentrations: $0.1 \mathrm{mM}(\mathrm{Ni} 1), 0.2 \mathrm{mM}$ (Ni2) and $0.5 \mathrm{mM}$ (Ni3). The seedlings without $\mathrm{Ni}^{2+}$ application were taken as control. Results showed that exogenous $\mathrm{Ni}^{2+}$ application improved the early growth of seedlings in terms of seedling length, basal diameter, biomass accumulation and seedling index. Substantial improvements were also observed regarding chl a, chl b, total chl contents and carotenoids in plants under $\mathrm{Ni}^{2+}$ application compared to CK. Furthermore, all $\mathrm{Ni}^{2+}$ treatments decreased the content of Malondialdehyde (MDA). Among all applied concentrations, Ni2 proved better regarding its promotive effects, however further research is needed to explore the molecular basis of Ni-induced modulations in seedlings of both rice cultivars.
\end{abstract}

Keywords: chlorophyll; nickel nitrate; rice; seedling; enzymes in nitrogen metabolism; anti-oxidant enzyme

\section{Introduction}

Rapid industrial development, urbanization and other anthropogenic activities are building pools of heavy metals in soils (Nagajyoti et al., 2010). These heavy metals, at an optimum concentration, act as essential micronutrients for the plants and play a beneficial role for plant growth, development and overall productivity.

Similarly, nickel is also recognized as the double-edged element for plants i.e., toxic at high concentrations whilst promotive at low/trace concentrations. However, long term nickel stress could induce significant inhibitory effects on shoots and roots growth, plant height, number of tillers, 1000 grain weight and paddy yield (Nazir and Asghar et al., 2015). Moreover, nickel $\left(\mathrm{Ni}^{2+}\right)$ toxicity caused decline in the activities of antioxidants and induced the accumulation of free proline in both leaves and roots in pea plants (Gajewska and Skłodowska, 2005). Exposure of detached leaves of rice seedlings to $\mathrm{NiSO}_{4}(1 \mathrm{mM})$ caused remarkable decline in activity of superoxide 
dismutase (SOD) and enhanced malondialdehyde (MDA) contents, thus caused leaf senescence (Shi and Zhoum 1998). Rice seedlings exposed to high $\mathrm{Ni}^{2+}$ concentrations caused substantial reduction in root and shoot growth along with substantial decline in fresh and dry biomass of rice plants (Rizwan and Imtiaz et al., 2017). A decline in the activities of anti-oxidants e.g., superoxide dismutase (SOD), catalase (CAT) and ascorbate peroxidase (APX) were noted with the increased $\mathrm{Ni}^{2+}$ concentrations in paddy leaves.

On the other hand, nickel is an essential element for high plants with a normal range of 0.01-5.00 mg kg${ }^{-1}$ dry weight (DW) (Welch, 1981); however, such reports are very few. For instance, application of $\mathrm{NiCl}_{2}\left(1-5 \mu \mathrm{mol} \mathrm{L}^{-1}\right)$ can effectively promote vegetative growth of rice seedlings (Wang et al., 1999). It also augmented the chlorophyll content, soluble protein, soluble sugars and peroxidase (POD) activity (Wang and Tian et al., 1999). Its involvement as a non-substitution component of urease seems to be the only proof of its beneficial effect in high plants (Gerendás and Polacco et al., 2015). Fishbein et al. (1997) indicated that $\mathrm{Ni}^{2+}$ is a necessary component of plant and bacterial urease which has an important role in catalysing the hydrolysis of urea into ammonia and carbon dioxide in plants. Polacco (1997) reported that soybean cells had an absolute requirement for $\mathrm{Ni}^{2+}$ while grown with urea as a sole $\mathrm{N}$ source in the presence of citrate. Gerendás et al. (2015) also proved that the nickel deficient paddies showed substantial reduction in growth and urea accumulation owing to the lack of urease activity. Ni-induced improvements in seed germination and early growth in rice mimics its stimulatory effects (Das and Kar et al., 1978; Mishra and Kar, 1974). Furthermore, low concentration of $\mathrm{Ni}^{2+}$ can promote the activities of peroxidase and ascorbic acid oxidase in alfalfa leaves and can enhance the disease resistance in crops (Theisen and Blincoe, 1984), nonetheless, the promotive effects of $\mathrm{Ni}^{2+}$ in high plants still needs further investigation. Present study investigated the effects of exogenous application of $\mathrm{Ni}^{2+}$ at lower concentrations on the physio-biochemical attributes and early growth of rice seedlings with the hypothesis that $\mathrm{Ni}^{2+}$ being a trace element could improve the early growth of rice if applied at low concentration.

\section{Materials and methods}

\section{Experimental details}

Pot experiment, between September to October in 2017, was conducted at Experimental Research Farm, College of Agriculture, South China Agricultural University, Guangzhou, $\left(23^{\circ} 09^{\prime} \mathrm{N}, 113^{\circ} 22^{\prime} \mathrm{E}\right.$ and $11 \mathrm{~m}$ from mean sea level) China.

The experimental soil in Guangzhou was sandy loam with $25.65 \%$ of organic matter content, $1.360 \%$ total N, $0.956 \%$ total $\mathrm{P}$, and $17.460 \%$ total $\mathrm{K}$. Before sowing, seeds of two popular rice cultivars i.e., Meixiangzhan 2 and Yuxiangyouzhan were soaked in water for $24 \mathrm{~h}$ at room temperature and germinated under moisture conditions. Geminated seeds were sown in plastic pots $(31 \mathrm{~cm}$ in diameter and $29 \mathrm{~cm}$ in height) and allowed to grow for 10 days then $\mathrm{Ni}^{2+}$ in the form of $\mathrm{Ni}\left(\mathrm{NO}_{3}\right)_{2}$ was foliar sprayed with three different concentrations i.e., $0.1,0.2$, and $0.5 \mathrm{mM}$ and regarded as $\mathrm{Ni} 1, \mathrm{Ni} 2$ and $\mathrm{Ni3}$, respectively. Pots without $\mathrm{Ni}^{2+}$ application were regarded as control (CK) The measurements were repeated in triplicate and averaged.

Thirty days old seedlings collected from each treatment, except those which were used for the determination of seedling growth, were harvested, washed and immediately stored at $-80^{\circ} \mathrm{C}$ till biochemical analyses (Fig. 1). 


$$
-359 \text { - }
$$

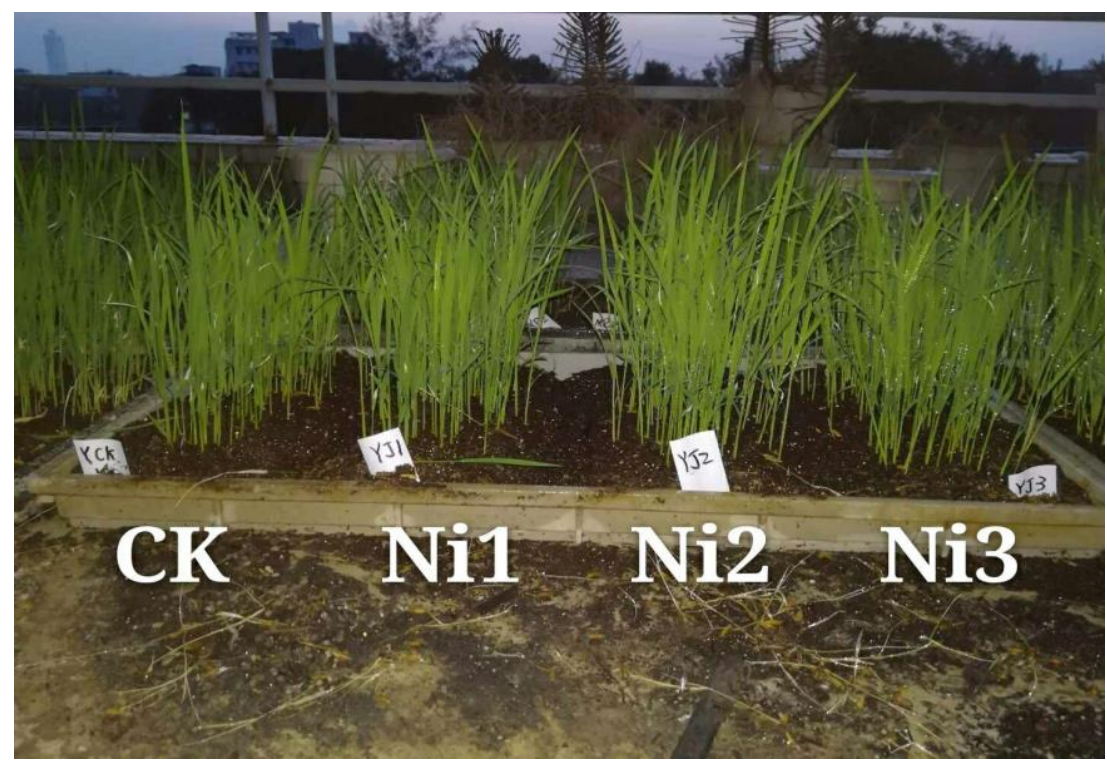

Figure 1. Experimental site

\section{Determination of seedling growth}

30 days old 10 seedlings from each treatment were randomly harvested for measuring plant height, basal diameter, dry biomass and seedling index. The seedling index was calculated as:

$$
\text { Seedling index }=\text { basal diameter } / \text { plant height } \times \text { dry weight }
$$

\section{Determination of soluble protein and malondialdehyde (MDA)}

Protein contents were estimated according to Bradford (1976) by using G-250 and expressed as ug $\mathrm{g}^{-1} \mathrm{FW}$. Malondialdehyde (MDA) content was measured according to the method of Luo and Zhong et al. (2017) with thiobarbituric acid. MDA reacted with thiobarbituric acid (TBA) and the absorbance was read at $532 \mathrm{~nm}, 600 \mathrm{~nm}$, and $450 \mathrm{~nm}$. The content of MDA was calculated as: MDA content $(\mu \mathrm{mol} / \mathrm{L})=6.45(\mathrm{OD} 532-\mathrm{OD}$ $600)-0.56 \mathrm{OD} 450$ and final result was expressed as $\mu \mathrm{mol} / \mathrm{g} \mathrm{FW}$.

\section{Determination of chlorophyll contents}

The fresh leaf samples $(0.5 \mathrm{~g})$ were extracted with $95 \%$ alcohol and the absorbance was read at $665 \mathrm{~nm}, 649 \mathrm{~nm}, 652 \mathrm{~nm}$ and 470nm and the chlorophyll contents were estimated according to Arnon (1949).

\section{Determination of anti-oxidants activities}

The peroxidase (POD, EC1.11.1.7) activity was measured with the methods of Pan et al. (2013). The reaction solution included enzyme extract $(50 \mu \mathrm{l})$ containing $1 \mathrm{ml}$ of $0.3 \% \mathrm{H}_{2} \mathrm{O}_{2}, 0.95 \mathrm{ml}$ of $0.2 \%$ guaiacol, and $1 \mathrm{ml}$ of $50 \mathrm{mM} \mathrm{l}^{-1}$ sodium phosphate buffer (pH 7.0). The absorbance was read at $470 \mathrm{~nm}$. One POD unit of enzyme activity was defined as the absorbance increase because of guaiacol oxidation by 0.01 (U/g FW). The superoxide dismutase (SOD, EC 1.15.1.1) activity was measured by using nitro 
blue tetrazolium (NBT) according to Pan et al. (2013). enzyme extract $(0.05 \mathrm{ml})$ was added into the reaction mixture containing $1.75 \mathrm{ml}$ of sodium phosphate buffer $(\mathrm{pH}$ 7.8 ), $0.3 \mathrm{ml}$ of $130 \mathrm{mM} \mathrm{1}^{-1}$ methionine buffer, $0.3 \mathrm{ml}$ of $750 \mu \mathrm{mol} 1^{-1}$ NBT buffer, $0.3 \mathrm{ml}$ of $100 \mu \mathrm{mol} \mathrm{1}^{-1}$ EDTA-Na 2 buffer and $0.3 \mathrm{ml}$ of $20 \mu \mathrm{mol}^{-1}$ lactoflavin. After the reaction, the change in color was measured at $560 \mathrm{~nm}$. One unit of SOD activity is equal to the volume of extract needed to cause $50 \%$ inhibition of the color reaction. Catalase (CAT, EC 1.11.1.6) activity was estimated with the methods devised by Aebi (1984). An aliquot of enzyme extract $(50 \mu \mathrm{l})$ was added to the reaction solution containing $1 \mathrm{ml}$ of $0.3 \% \mathrm{H}_{2} \mathrm{O}_{2}$ and $1.95 \mathrm{ml}$ of sodium phosphate buffer. The absorbance was recorded at $240 \mathrm{~nm}$. One CAT unit of enzyme activity was defined as the absorbance decrease by 0.01 (U/g FW).

\section{Determination of nitrogen metabolism enzymes activities}

The activity of nitrate reductase (NR) was measured by using the methods of Sun et al. (2009). One unit of $\mathrm{NR}$ activity is defined as $\mathrm{NaNO}_{2} \mu \mathrm{g}$ formed per gram of fresh samples per hour. The activities of glutamic oxaloacetic transaminase (GOT) were measured by using the methods devised by Ebeid et al. (1981). The aminotransferase activity was expressed by pyruvate formed in $30 \mathrm{~min}$. The activities of glutamine synthetase (GS) and glutamine oxoglutarate aminotransferase (GOGAT) were measured according to Lin and Kao (1996). One unit of GS activity is defined as 1 pmol Lglutamate $\gamma$-monohydroxamate formed per min. The reaction mixture $(1 \mathrm{ml}, \mathrm{pH} 8.0)$ contained 80 pmol Tris-HCl buffer, 40 pmol L-glutamic acid, 8 pmol ATF', 24 pmol $\mathrm{MgSO}_{4}$, and $16 \mathrm{pmol} \mathrm{NH}_{2} \mathrm{OH}$. The final $\mathrm{pH}$ was 8.0. The reaction was started by addition of the enzyme extract and stopped by adding $2 \mathrm{~mL}$ of $2.5 \% \mathrm{FeCl}_{2}$ and $5 \%$ trichloroacetic acid in $1.5 \mathrm{M} \mathrm{HCl}$ after $30 \mathrm{~min}$ incubation at $30{ }^{\circ} \mathrm{C}$. One unit of GOGAT activity is defined as a decrease of $1 \mathrm{OD}_{340}$ per min. The reaction was started by adding L-glutamine immediately following the enzyme preparation. The decline in absorbance was recorded at $340 \mathrm{~nm}$.

\section{Statistical analyses}

Data were analyzed using statistical software 'Statistix 8.1'(Analytical Software, Tallahassee, FL, USA) while differences amongst means were separated by using least significant difference (LSD) test at 5\% probability level. 'Origin 8.1' (OriginLab Co., Northampton, MA, USA) was used for graphical representation.

\section{Results}

\section{Seedling growth}

No significant difference was noted in seedling length for Meixiangzhan 2 and basal diameter for both cultivars among all $\mathrm{Ni}^{2+}$ treatments and $\mathrm{CK}$, however seedling length was substantially increased under all $\mathrm{Ni}^{2+}$ treatments than $\mathrm{CK}$ for Yuxiangyouzhan 2. The seedling fresh and dry weight were increased by $19.58-32.23 \%$ and $23.08-26.93 \%$ (for Yuxiangyouzhan) as well as 24.65-32.93\% and 29.16-46.88\% (for Meixiangzhan 2), respectively. Furthermore, the highest seedling index i.e., $1.14 \pm 0.03$ and $0.78 \pm 0.05$ was recorded in Ni2 for both Yuxiangyouzhan and Meixiangzhan 2 (Table 1). 


$$
-361 \text { - }
$$

Table 1. Effect of $\mathrm{Ni}^{2+}$ application on rice seedling quality

\begin{tabular}{c|c|c|c|c|c|c}
\hline Cultivars & $\begin{array}{c}\text { Treatme } \\
\text { nt }\end{array}$ & $\begin{array}{c}\text { Seedling } \\
\text { length } \\
\text { (cm) }\end{array}$ & $\begin{array}{c}\text { Basal } \\
\text { diameter } \\
(\mathbf{m m})\end{array}$ & $\begin{array}{c}\text { Fresh } \\
\text { weight } \\
\text { (mg) }\end{array}$ & $\begin{array}{c}\text { Dry weight } \\
(\mathbf{m g})\end{array}$ & Seedling index \\
\hline \multirow{5}{*}{ Yuxiangyouzhan } & $\mathrm{CK}$ & $15.50 \pm 0.13 \mathrm{~b}$ & $1.32 \pm 0.01 \mathrm{a}$ & $55.33 \pm 2.64 \mathrm{~b}$ & $10.83 \pm 1.09 \mathrm{~b}$ & $0.92 \pm 0.09 \mathrm{~b}$ \\
& $\mathrm{Ni} 1$ & $17.17 \pm 0.67 \mathrm{a}$ & $1.35 \pm 0.03 \mathrm{a}$ & $67.83 \pm 5.13 \mathrm{a}$ & $13.33 \pm 0.45 \mathrm{a}$ & $1.05 \pm 0.04 \mathrm{ab}$ \\
& $\mathrm{Ni} 2$ & $16.10 \pm 0.49 \mathrm{ab}$ & $1.34 \pm 0.04 \mathrm{a}$ & $66.17 \pm 4.28 \mathrm{ab}$ & $13.67 \pm 0.39 \mathrm{a}$ & $1.14 \pm 0.03 \mathrm{a}$ \\
& $\mathrm{Ni} 3$ & $16.97 \pm 0.65 \mathrm{ab}$ & $1.32 \pm 0.02 \mathrm{a}$ & $73.17 \pm 3.27 \mathrm{a}$ & $13.75 \pm 0.44 \mathrm{a}$ & $1.07 \pm 0.03 \mathrm{ab}$ \\
\hline & $\mathrm{CK}$ & $15.40 \pm 0.92 \mathrm{a}$ & $1.095 \pm 0.02 \mathrm{a}$ & $47.60 \pm 2.88 \mathrm{~b}$ & $8.00 \pm 0.29 \mathrm{~b}$ & $0.57 \pm 0.02 \mathrm{~b}$ \\
Meixiangzhan 2 & $\mathrm{Ni} 1$ & $17.28 \pm 1.21 \mathrm{a}$ & $1.10 \pm 0.07 \mathrm{a}$ & $61.40 \pm 3.55 \mathrm{a}$ & $11.75 \pm 0.14 \mathrm{a}$ & $0.75 \pm 0.01 \mathrm{a}$ \\
& $\mathrm{Ni} 2$ & $15.85 \pm 0.76 \mathrm{a}$ & $1.14 \pm 0.03 \mathrm{a}$ & $62.80 \pm 1.76 \mathrm{a}$ & $10.83 \pm 0.67 \mathrm{a}$ & $0.78 \pm 0.05 \mathrm{a}$ \\
& $\mathrm{Ni} 3$ & $16.27 \pm 0.95 \mathrm{a}$ & $1.10 \pm 0.07 \mathrm{a}$ & $59.33 \pm 5.25 \mathrm{a}$ & $10.33 \pm 0.93 \mathrm{a}$ & $0.70 \pm 0.06 \mathrm{ab}$ \\
\hline
\end{tabular}

Data in the table are tested with Statitix 8 by LSD $(\mathrm{P}<0.05)$. Values with different small letters in the same line have significant difference

\section{Chlorophyll contents}

Exogenous $\mathrm{Ni}^{2+}$ application affected the chlorophyll contents significantly. Compared with CK, the contents of chl a were increased by $6.14-20.71 \%$ for Yuxiangyouzhan and 1.23-8.12\% for Meixiangzhan 2. The contents of chl b were improved by $10.46-13.5 \%$ in $\mathrm{Ni} 2$ and $\mathrm{Ni3}$, respectively for Yuxiangyouzhan whilst increased by 3.22, 6.66 and 3.79\% in Ni1, Ni2 and Ni3 for Meixiangzhan 2. Likewise, the total chl contents were increased by $3.97 \%, 16.33 \%$ and $16.96 \%$ for Yuxiangyouzhan and 2.61\%, 7.55\% and 2.19\% for Meixiangzhan 2 under Ni1, Ni2 and $\mathrm{Ni3}$, respectively as compared with CK. Furthermore, different nickel applications improved carotenoid contents significantly for both cultivars. For instance, compared with $\mathrm{CK}$, the Ni1, Ni2 and Ni3 resulted in 8.68, 26.40 and $21.88 \%$ higher carotenoid contents than CK for Yuxiangyouzhan and 3.66, 10.44 and 1.46 higher carotenoid contents for Meixiangzhan 2, respectively (Fig. 2).

\section{Nitrogen metabolism enzymes}

Overall, all $\mathrm{Ni}^{2+}$ treatments regulated the activities of key enzymes involved in nitrogen metabolism (Table 2). The NR activities were increased by 12.27, 18.13 and $10.56 \%$ for Yuxiangyouzhan and 8.24, 20.03 and 25.56\% higher for Meixiangzhan 2 in $\mathrm{Ni} 1, \mathrm{Ni} 2$ and Ni3, respectively. The activities of GS in all Ni treatments were found statistically similar $(\mathrm{P}>0.05)$ for Yuxiangyouzhan whereas the highest GS activity was recorded in Ni1 while lowest in Ni3.

Meanwhile, no significant difference was recorded among Ni1, Ni2 and CK for GOGAT activities while lowest GOGAT activity was recorded in Ni3 for Yuxiangyouzhan. However, for Meixiangzhan 2, 15.12\% and $15.15 \%$ lower activity of GOGAT was recorded in $\mathrm{Ni} 2$ and $\mathrm{Ni} 3$ whilst Ni1 remained similar with $\mathrm{CK}$. Compared with control, activities of GOT in Ni1, Ni2 and Ni3 were 1.09, 1.22 and 1.24 fold higher for Yuxiangyouzhan while 1.21, 1.16 and 1.02 fold higher for Meixiangzhan 2. Moreover, the activities of GPT were improved by 28.74, 51.95 and $29.47 \%$ in Ni1, Ni2 and Ni3 for Yuxiangyouzhan whilst 49.38, 24.99 and 16.82\% for Meixiangzhan 2. 

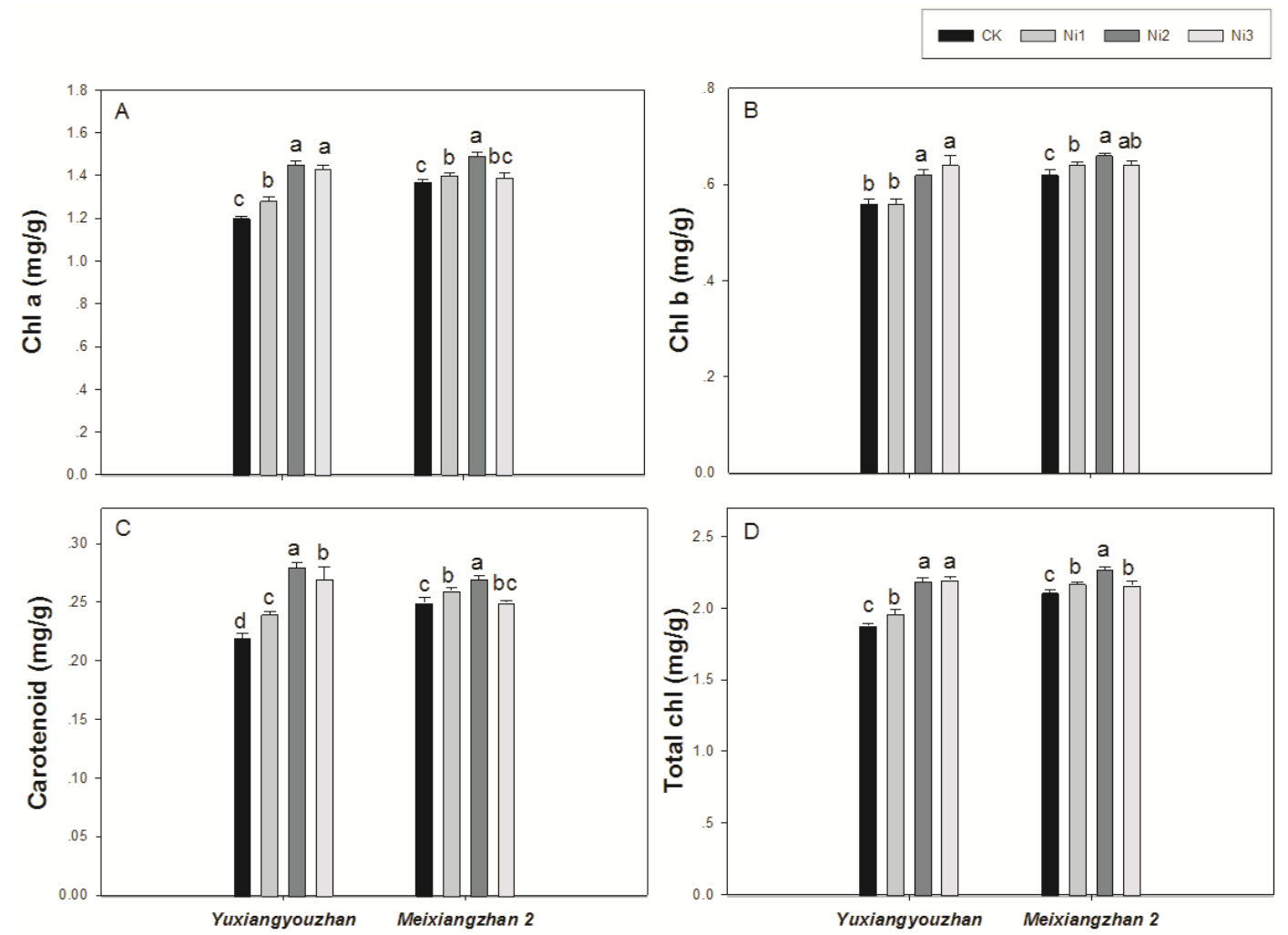

Figure 2. Effect of $\mathrm{Ni}^{2+}$ application on chlorophyll content

Table 2. Effect of $\mathrm{Ni}^{2+}$ application on nitrogen metabolism

\begin{tabular}{|c|c|c|c|c|c|c|}
\hline Cultivar & Treatment & $\begin{array}{c}\text { NR activity } \\
\left({\left.\text { ug } \cdot \mathrm{g}^{-1}\right)}^{-1}\right.\end{array}$ & $\underset{\left(\mathrm{umol}^{\left.-\mathrm{g}^{-1} \cdot \mathrm{min}^{-1}\right)}\right.}{\text { GS activity }}$ & $\begin{array}{l}\text { GOGAT activity } \\
\left(\text { umol }^{\prime} \cdot \mathbf{g}^{-1} \cdot \mathbf{m i n}^{-1}\right)\end{array}$ & $\begin{array}{l}\text { GOT activity } \\
\left(\mathrm{umol}^{\prime} \mathrm{g}^{-1} \cdot \mathbf{h}^{-1}\right)\end{array}$ & 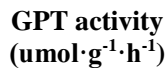 \\
\hline \multirow{4}{*}{ Yuxiangyouzhan } & $\mathrm{CK}$ & $56.74 \pm 7.1 \mathrm{~b}$ & $0.36 \pm 0.00 \mathrm{a}$ & $0.30 \pm 0.01 \mathrm{a}$ & $30.59 \pm 0.55 \mathrm{c}$ & $37.36 \pm 1.37 \mathrm{c}$ \\
\hline & Ni1 & $63.71 \pm 2.11 \mathrm{a}$ & $0.34 \pm 0.02 \mathrm{a}$ & $0.34 \pm 0.01 \mathrm{a}$ & $33.58 \pm 0.28 \mathrm{~b}$ & $48.10 \pm 1.15 b$ \\
\hline & $\mathrm{Ni} 2$ & $67.03 \pm 1.25 \mathrm{a}$ & $0.37 \pm 0.04 \mathrm{a}$ & $0.32 \pm 0.01 \mathrm{a}$ & $37.18 \pm 0.42 \mathrm{a}$ & $56.77 \pm 0.54 \mathrm{a}$ \\
\hline & $\mathrm{Ni3}$ & $62.74 \pm 1.13 \mathrm{a}$ & $0.37 \pm 0.02 \mathrm{a}$ & $0.24 \pm 0.03 \mathrm{~b}$ & $38.00 \pm 0.64 \mathrm{a}$ & $48.37 \pm 0.64 \mathrm{~b}$ \\
\hline \multirow{4}{*}{ Meixiangzhan 2} & $\mathrm{CK}$ & $58.93 \pm 1.23 d$ & $0.41 \pm 0.02 b$ & $0.33 \pm 0.01 \mathrm{a}$ & $34.89 \pm 0.59 \mathrm{~b}$ & $42.73 \pm 3.00 \mathrm{c}$ \\
\hline & Ni1 & $63.79 \pm 0.68 \mathrm{c}$ & $0.53 \pm 0.06 \mathrm{a}$ & $0.32 \pm 0.01 \mathrm{ab}$ & $42.36 \pm 1.78 \mathrm{a}$ & $63.83 \pm 1.20 \mathrm{a}$ \\
\hline & $\mathrm{Ni} 2$ & $70.74 \pm 0.82 b$ & $0.38 \pm 0.02 \mathrm{~b}$ & $0.28 \pm 0.01 \mathrm{ab}$ & $40.57 \pm 0.24 \mathrm{a}$ & $53.41 \pm 0.37 \mathrm{~b}$ \\
\hline & $\mathrm{Ni} 3$ & $74.00 \pm 1.02 \mathrm{a}$ & $0.29 \pm 0.01 \mathrm{c}$ & $0.28 \pm 0.02 \mathrm{~b}$ & $35.61 \pm 0.10 \mathrm{~b}$ & $49.92 \pm 0.77$ \\
\hline
\end{tabular}

Data in the table are tested with Statitix 8 by LSD $(\mathrm{P}<0.05)$. Values with different small letters in the same line have significant difference

\section{MDA contents, osmo-protectants and anti-oxidant responses}

Exogenous $\mathrm{Ni}^{2+}$ application regulated the anti-oxidative enzymatic activities in terms of SOD, POD and CAT (Table 3). Compared with CK, 8.44 and 8.03\% higher POD activities were recorded in $\mathrm{Ni1}$ and $\mathrm{Ni3}$ for Yuxiangyouzhan while highest POD activity (21.51\% higher than CK) was found for Meixiangzhan 2 in Ni1. The SOD activities were also increasaed by $8.68,9.51$ and $27.73 \%$ for Yuxiangyouzhan whilst 47.58, 29.66 and $27.73 \%$ for Meixianghzhan 2 in $\mathrm{Ni} 1, \mathrm{Ni} 2$ and Ni3 treatments, respectively. Similarly, compared with CK, the CAT activities increased with 13.48, 30.65 and $11.52 \%$ in Ni1, Ni2 and Ni3, respectively for Yuxiangyouzhan while increased by 16.89 and $19.37 \%$ in Ni1 and Ni3, respectively for Meixiangzhan 2. 
The MDA contents were found significantly lower under all $\mathrm{Ni}^{2+}$ treatments than $\mathrm{CK}$ for both cultivars. The MDA contents were reduced by 21.96, 26.02, and $35.81 \%$ for Yuxiangyouzhan and 31.43, 21.54, and 13.34\% for Meixiangzhan 2 in Ni1, Ni2, and Ni3 compared to CK. Furthermore, the protein contents were increased by 20.43 and $13.97 \%$ in $\mathrm{Ni} 2$ and Ni3, respectively for Yuxiangyouzhan while it was $31.74 \%$ higher in Ni1 for Meixiangzhan 2 compared with CK.

Table 3. Effect of $\mathrm{Ni}^{2+}$ application on MDA contents, osmo-protectants and anti-oxidant responses

\begin{tabular}{|c|c|c|c|c|c|c|}
\hline Cultivar & Treatment & $\begin{array}{c}\text { Peroxidase } \\
\text { activity } \\
\left(\mathbf{U} \cdot \mathbf{g}^{-1} \cdot \mathbf{m i n}^{-1)}\right.\end{array}$ & $\begin{array}{c}\text { Super-oxide } \\
\text { dismutase } \\
\text { activity } \\
\text { (U·g-) }\end{array}$ & $\begin{array}{c}\text { Catalase } \\
\text { activity } \\
\left(\mathrm{U} \cdot \mathrm{g}^{-1} \cdot \mathrm{min}^{-1}\right)\end{array}$ & $\begin{array}{c}\text { Malondialdehyde } \\
\text { content } \\
\left(\mathrm{umol} \cdot \mathrm{g}^{-1}\right)\end{array}$ & $\begin{array}{c}\text { Soluble protein } \\
\text { content } \\
\left(\mathrm{ug} \cdot \mathrm{g}^{-1}\right)\end{array}$ \\
\hline \multirow{4}{*}{ Yuxiangyouzhan } & CK & $315.94 \pm 10.01 \mathrm{c}$ & $127.61 \pm 0.54 b$ & $140.42 \pm 2.10 \mathrm{c}$ & $2.52 \pm 0.04 \mathrm{a}$ & $27.14 \pm 0.70 \mathrm{c}$ \\
\hline & Ni1 & $342.60 \pm 3.25 b$ & $138.69 \pm 4.14 b$ & $159.35 \pm 0.66 \mathrm{~b}$ & $1.97 \pm 0.04 b$ & $27.32 \pm 0.18 \mathrm{c}$ \\
\hline & $\mathrm{Ni} 2$ & $321.634 .16 \mathrm{c}$ & $139.74 \pm 3.70 \mathrm{~b}$ & $183.46 \pm 1.33 \mathrm{a}$ & $1.87 \pm 0.06 \mathrm{~b}$ & $32.68 \pm 0.59 \mathrm{a}$ \\
\hline & $\mathrm{Ni3}$ & $360.90 \pm 0.48 \mathrm{a}$ & $163.00 \pm 0.36 \mathrm{a}$ & $156.60 \pm 1.73 b$ & $1.619 \pm 0.05 \mathrm{c}$ & $30.93 \pm 0.92 b$ \\
\hline \multirow{4}{*}{ Meixiangzhan 2} & CK & $345.07 \pm 2.38 b$ & $106.49 \pm 1.21 \mathrm{c}$ & $117.45 \pm 3.85 b$ & $2.35 \pm 0.05 \mathrm{a}$ & $25.66 \pm 0.85 b$ \\
\hline & Ni1 & $419.28 \pm 3.66 \mathrm{a}$ & $157.16 \pm 5.58 \mathrm{a}$ & $137.29 \pm 4.07 \mathrm{a}$ & $1.61 \pm 0.00 \mathrm{~d}$ & $33.81 \pm 1.63 \mathrm{a}$ \\
\hline & $\mathrm{Ni} 2$ & $342.77 \pm 0.76 b$ & $138.08 \pm 2.46 b$ & $114.13 \pm 1.32 b$ & $1.84 \pm 0.05 \mathrm{c}$ & $25.87 \pm 0.29 \mathrm{~b}$ \\
\hline & $\mathrm{Ni3}$ & $341.32 \pm 1.22 \mathrm{~b}$ & $137.78 \pm 8.59 b$ & $140.20 \pm 1.73 \mathrm{a}$ & $2.04 \pm 0.05 b$ & $23.90 \pm 0.26 \mathrm{~b}$ \\
\hline
\end{tabular}

Data in the table are tested with Statitix 8 by LSD $(\mathrm{P}<0.05)$. Values with different small letters in the same line have significant difference

\section{Correlation analysis}

Significant and positive correlation between seedling index and seedling fresh weight was observed. The same correlation was found among dry weight and activities of both SOD and CAT. Moreover, there also existed a similar correlation between total chlorophyll content and GOT activity (Table 4).

\section{Discussion}

Recently, the research on plant micro-nutrition has been given a renowned attention due to its significant effects on plant growth, development and overall crop productivity and grain nutritional qualities as well (Taylor and Harrier, 2001). Previously, $\mathrm{Ni}^{2+}$ has been recognized as an essential micronutrient for legumes and possibly all high plants and is a necessary constituent of the enzyme 'urease' (Eskew and Welch et al., 1983). In this study, the seedling growth attributes i.e., seedling length, basal diameter, fresh and dry biomass as well asseedling index were substaintially improved by exogenous $\mathrm{Ni}^{2+}$ application. For example, remarkable improvement was found in height, fresh weight and dry weight under Ni1 treatment for both cultivars while highest value of seedling index was recorded in Ni2 for Yuxiangyouzhan and Meixiangzhan 2 which are 1.74 and 0.78 . The values of the seedling index were calculated considering height, dry weight and basal diameter which all are the result of growth and development. Thus, seedling index represents the growth status of seedlings to a certain extent. In this study, $\mathrm{Ni}^{2+}$ treatments enhanced the seedling index and it might have indicated that $\mathrm{Ni}^{2+}$ application at low concentration is able to improve or stimulate the growth and development of rice seedlings. 
Table 4. Relationship among the growth and biochemical parameters

\begin{tabular}{|c|c|c|c|c|c|c|c|c|c|c|c|c|c|c|c|c|}
\hline Index & $\begin{array}{l}\text { Seedling } \\
\text { index }\end{array}$ & Height & $\begin{array}{c}\text { Basal } \\
\text { diameter }\end{array}$ & $\begin{array}{l}\text { Fresh } \\
\text { weight }\end{array}$ & $\begin{array}{c}\text { Dry } \\
\text { weight }\end{array}$ & Total chl & Chl a & Chl b & POD & SOD & CAT & NR & GS & GOGAT & GOT & GPT \\
\hline Height & 0.362 & & & & & & & & & & & & & & & \\
\hline Basal diameter & $0.933 * *$ & 0.163 & & & & & & & & & & & & & & \\
\hline Fresh weight & $0.782 *$ & $0.712 *$ & 0.569 & & & & & & & & & & & & & \\
\hline Dry weight & $0.918 * *$ & 0.67 & $0.741 *$ & $0.932 * *$ & & & & & & & & & & & & \\
\hline Total chl & -0.171 & 0.106 & -0.456 & 0.261 & 0.042 & & & & & & & & & & & \\
\hline Chl a & -0.077 & 0.11 & -0.364 & 0.31 & 0.115 & $0.990 * *$ & & & & & & & & & & \\
\hline Chl b & -0.357 & 0.069 & -0.62 & 0.13 & -0.119 & $0.966 * *$ & $0.921 * *$ & & & & & & & & & \\
\hline POD & -0.46 & 0.583 & -0.643 & -0.023 & -0.101 & 0.319 & 0.246 & 0.43 & & & & & & & & \\
\hline SOD & 0.489 & $0.805^{*}$ & 0.228 & $0.842 * *$ & $0.761 *$ & 0.353 & 0.342 & 0.329 & 0.407 & & & & & & & \\
\hline CAT & $0.862 * *$ & 0.403 & $0.756^{*}$ & 0.63 & $0.822 *$ & -0.133 & -0.043 & -0.303 & -0.274 & 0.414 & & & & & & \\
\hline NR & -0.08 & 0.168 & -0.336 & 0.311 & 0.115 & 0.631 & 0.615 & 0.637 & 0.198 & 0.287 & 0.026 & & & & & \\
\hline GS & -0.254 & 0.278 & -0.353 & -0.139 & -0.07 & 0.208 & 0.187 & 0.22 & 0.688 & 0.221 & -0.228 & -0.341 & & & & \\
\hline GOGAT & -0.116 & -0.042 & -0.029 & -0.414 & -0.179 & -0.427 & -0.369 & -0.496 & 0.113 & -0.499 & 0.07 & -0.28 & 0.279 & & & \\
\hline GOT & -0.153 & 0.43 & -0.464 & 0.323 & 0.167 & $0.839 * *$ & $0.818^{*}$ & $0.824 *$ & 0.672 & 0.57 & -0.153 & 0.452 & 0.611 & -0.215 & & \\
\hline GPT & 0.058 & 0.58 & -0.283 & 0.405 & 0.375 & 0.648 & 0.657 & 0.591 & 0.679 & 0.601 & 0.201 & 0.519 & 0.539 & 0.078 & $0.0887 * *$ & \\
\hline Protein & 0.497 & 0.533 & 0.302 & 0.475 & 0.632 & 0.208 & 0.252 & 0.094 & 0.331 & 0.627 & 0.554 & -0.208 & 0.648 & 0.068 & 0.494 & 0.628 \\
\hline
\end{tabular}


Previously, it was observed that exposure of plants to $10 \mu \mathrm{M} \mathrm{Ni}{ }^{2+}$ lead to a slight increase in fresh mass while $200 \mu \mathrm{M} \mathrm{Ni}^{2+}$ inhibited shoot growth. It also caused a decline in chlorophyll content, an accumulation of proline hence visible symptoms of $\mathrm{Ni}$ toxicity. Nickel deficiency disrupted the ureide catabolism in foliage. It also induced accumulation of xanthine, allantoic acid, ureidoglycolate and citrulline while total ureides, urea concentration and urease activity were reduced (Bai and Reilly et al., 2006). Furthermore, an earlier study found that a Ni-binding protein is necessary for urease activity which is encoded by soybean Eu3 gene (Freyermuth and Bacanamwo et al., 2000).

Exogenous $\mathrm{Ni}^{2+}$ application also enhanced the chl a, chl b, total chl contents and carotenoids. The results of the present study showed that $\mathrm{Ni}^{2+}$ treatments increased the content of chl especially $\mathrm{Ni} 3$ and Ni4. Highest total chl content was recorded in $\mathrm{Ni} 2$ for Yuxiangyouzhan and in Ni3 for Meixiangzhan 2 while Ni3 had highest content of Chl a for both cultivars. Chl a can have an important role in converting light energy into electrical and chemical energy (Asadov et al., 1995). The increment of photosynthetic pigment implied that nickel treatments could enhance the seedling's photosynthesis thus promoting the carbon metabolism and dry matter accumulation rate.

Furthermore, higher activities of NR, GOT and GPT were noted in $\mathrm{Ni}^{2+}$ treatments. Nitrate Reductase (NR), glutamic-oxalacetic transaminase (GOT) and glutamate pyruvic (GPT) are key enzymes for nitrogen metabolism in plants. NR, through its catalytic reaction, not only regulates nitrate reduction but also influences the carbon metabolism of photosynthesis (Jamal and Fazli et al., 2006). Deckard et al. grew six corn (Zea mays L.) hybrids in field conditions with supplemental $\mathrm{N}$ and irrigation. This experiment proved that there exists a positive relation between nitrate reductase activity and grain protein and yield. The increment of enzymatic activities for nitrogen metabolism mean that nickel treatments could enhance nitrogen metabolism inside the seedling. It will, further, promote the uptake of soil nutrients and increase the nitrogen utilization.

In addition, Ni treatments modulated anti-oxidant responses i.e., POD, SOD and CAT. These results corroborated with Silva et al. (2012) who found that Ni played an important role in plant growth and $\mathrm{N}$ uptake in crops supplied with urea in calcareous soils. $\mathrm{Ni}^{2+}$ deficiency affects plant growth, plant senescence, nitrogen metabolism, iron uptake and disease resistance. Furthermore, $\mathrm{Ni}^{2+}$ is absorbed and redistributed in plants via cation and/or metal-ligand complex transport systems. Superoxide dismutase (SOD), peroxidase (POD) and catalase (CAT) collectively build an enzymatic defense system. They synergistically, defend cell membrane system from getting damaged by superoxide free radical. They also inhibit membrane lipid peroxidation and decrease malondialdehyde (MDA) content, in order to reduce damage to the plant cells (Jebara and Jebara et al., 2005). MDA is one of the most important products of membrane lipid peroxidation which can react with free amino acids, phospholipids and may produce ethylene in cellular membranes (Rakwal and Agrawal et al., 2003). So, in the study of plant resistance, physical and physiological aging is a commonly used indicator. MDA content can be a measure of the membrane lipid peroxidation. Thus, it can be used in indirect determination of membrane system damage and plants resistance. Moreover, soluble protein also has a role in osmo-regulation and maintaining cellular structures and functions while anti-oxidants focus on quenching reactive oxygen species (ROS). For instance, SOD is involved in catalyzing the dismutation of superoxide radical whereas POD and CAT are involved in scavenging $\mathrm{H}_{2} \mathrm{O}_{2}$ (Sairam and Srivastava, 
2000). So, antioxidant enzyme activity can reflect the resistance of plants to some extent. The improvements in antioxidant enzyme activity and protein content implied that exogenous application of nickel nitrate could have a 'phytosanitary' effect on rice seedlings thus enhancing their resistance.

\section{Conclusion}

The exogenous $\mathrm{Ni}^{2+}$ application improved seedling growth and development. It also enhanced the activities of key enzymes involved in nitrogen metabolism and antioxidant defence enzymes. Among $\mathrm{Ni}^{2+}$ treatments, $\mathrm{Ni} 2$ proved better than other $\mathrm{Ni}^{2+}$ doses for both Yuxiangyouzhan and Meixiangzhan 2. Even though, application of $\mathrm{Ni}^{2+}$ at low concentration could improve the early growth of rice, further investigations are required at physiological and molecular level in order to reveal the exact mechanism of Ni-induced promotive effects in plants. In addition, there are small amount of nitrogen inside nickel nitrate which might affect the result of this study, more research should be carried out with different nickel resources.

Acknowledgements. This study was supported by the National Natural Science Foundation of China (31271646), The World Bank Loan Agricultural Pollution Control Project in Guangdong (07241510A08N3684), The Technology System of Modern Agricultural Industry in Guangdong (2017LM1098) and the Innovation and Entrepreneurship Training Program for College Student (201710564005, 201710564012).

\section{REFERENCES}

[1] Aebi, H. (1984): Catalase in vitro. - Methods Enzymol 105: 121-126.

[2] Asadov, A. A., Kotlyarova, N. V., Zulfugarov, I. S. Aliyev, D. A. (1995): Spectral characteristics and orientation of native forms of pigments in the chloroplasts of barley seedlings on continuous and discontinuous illumination. - Biofizika 40(2): 245-251.

[3] Bai, C., Reilly, C. C., Wood, B. W. (2006): Nickel deficiency disrupts metabolism of ureides, amino acids, and organic acids of young pecan foliage. - Plant Physiology 140: 433-43.

[4] Bradford, M. M. (1976): A rapid and sensitive method for the quantitation of microgram quantities of protein utilizing the principle of protein-dye binding. - Analytical Biochemistry 72: 248-254.

[5] Das, P. K., Kar, M., Mishra, D. (1978): Nickel nutrition of plants: I. Effect of nickel on some oxidase activities during rice (Oryza sativa L.) seed germination. - Zeitschrift für Pflanzenphysiologie 90: 225-233.

[6] Ebeid, M., Eder, J., Kutáček, M., Piovarči, A. (1981): Transaminase GOT and GPT activity in extirped sprouts of normal and opaque-2 Maize (Zea mays L.) seedlings. Biologia Plantarum 23: 345-350.

[7] Eskew, D. L., Welch, R. M., Cary, E. E. (1983): Nickel: an essential micronutrient for legumes and possibly all higher plants. - Science 222: 621-3.

[8] Freyermuth, S. K., Bacanamwo, M., Polacco, J. C. (2000): The soybean Eu3 gene encodes an Ni-binding protein necessary for urease activity. - Plant Journal for Cell Molecular Biology 21: 53.

[9] Gajewska, E., Skłodowska, M. (2005): Antioxidative responses and proline level in leaves and roots of pea plants subjected to nickel stress. - Acta Physiologiae Plantarum 27: 329-340. 


$$
-367 \text { - }
$$

[10] Gerendás, J., Zhu, Z., Sattelmacher, B. (1998): Influence of N and Ni supply on nitrogen metabolism and urease activity in rice (Oryza sativa L.). - Journal of Experimental Botany 49: 1545-1554.

[11] Gerendás, J., Polacco, J. C., Freyermuth, S. K., Sattelmacher, B. (2015): Significance of nickel for plant growth and metabolism. - Journal of Plant Nutrition and Soil Science $=$ Zeitschrift fuer Pflanzenernaehrung und Bodenkunde 162: 241-256.

[12] Jamal, A., Fazli, I. S., Ahmad, S., Abdin, M. Z., Yun, S. J. (2006): Effect of nitrogen and sulphur application on nitrate reductase and ATP-sulphurylase activities in soybean. Korean Journal of Crop Science 51(4): 298-302.

[13] Jebara, S., Jebara, M., Limam, F., Aouani, M. E. (2005): Changes in ascorbate peroxidase, catalase, guaiacol peroxidase and superoxide dismutase activities in common bean (Phaseolus vulgaris) nodules under salt stress. - Journal of Plant Physiology 162: 929-936.

[14] Lin, C. C., Kao, C. H. (1996): Disturbed ammonium assimilation is associated with growth inhibition of roots in rice seedlings caused by $\mathrm{NaCl}$. - Plant Growth Regulation 18: 233-238.

[15] Luo, H., Zhong, Z., Nie, J., Tang, X. (2017): Effects of ultrasound on physiological characters, yield and quality of rice Yuejingsimiao. - China Rice 23(2): 64-67.

[16] Mishra, D., Kar, M. (1974): Nickel in plant growth and metabolism. - Botanical Review 40: 395-452.

[17] Nazir, H., Asghar, H. N., Zahir, Z. A., Akhtar, M. J., Saleem, M. (2015): Judicious use of kinetin to improve growth and yield of rice in nickel contaminated soil. - International Journal of Phytoremediation 18: 651.

[18] Polacco, J. C. (1977): Is nickel a universal component of plant ureases? - Plant Science Letters 10: 249-255.

[19] Rakwal, R., Agrawal, G. K., Kubo, A., Yonekura, M., Tamogami, S., Saji, H., Iwahashi, H. (2003): Defense/stress responses elicited in rice seedlings exposed to the gaseous air pollutant sulfur dioxide. - Environmental, Experimental Botany 49: 223-235.

[20] Rizwan, M., Imtiaz, M., Dai, Z., Mehmood, S., Adeel, M., Liu, J., Tu, S. (2017): Nickel stressed responses of rice in $\mathrm{Ni}$ subcellular distribution, antioxidant production, and osmolyte accumulation. - Environmental Science, Pollution Research International 2017: $1-12$.

[21] Sairam, R. K., Srivastava, G. C. (2000): Induction of oxidative stress and antioxidant activity by hydrogen peroxide treatment in tolerant and susceptible wheat genotypes. Biologia Plantarum 43: 381-386.

[22] Shi, G., Zhou, Q. (1998): Effect of nickel on lipid peroxidation in isolated rice leaves. Guihaia.

[23] Silva, J. A. T. D., Naeem, M., Idrees, M. (2012): Beneficial and toxic effects of nickel in relation to medicinal and aromatic plants. - Medicinal and Aromatic Plant Science and Biotechnology 6(Special Issue 1): 94-104.

[24] Sun, Y. J., Sun, Y. Y., Xu-Yi, L. I., Guo, X., Jun, M. A. (2009): Relationship of nitrogen utilization and activities of key enzymes involved in nitrogen metabolism in rice under water-nitrogen interaction. - Acta Agronomica Sinica 35: 2055-2063.

[25] Taylor, J., Harrier, L. A. (2001): A comparison of development and mineral nutrition of micropropagated Fragaria $\mathrm{x}$ ananassa cv. Elvira (strawberry) when colonised by nine species of arbuscular mycorrhizal fungi. - Applied Soil Ecology 18: 205-215.

[26] Theisen, M. O., Blincoe, C. (1984): Biochemical form of nickel in alfalfa. - Journal of Inorganic Biochemistry 21: 137-146.

[27] Wang, Y., Tian, T., Fu, H. (1999): Effects of nickel on growth of rice seedling. - Journal of Central China Normal University 33: 104-107.

[28] Welch, R. M. (1981): The biological significance of nickel. - Journal of Plant Nutrition 3: 345-356. 